\title{
Early herding practices revealed through organic residue analysis of pottery from the early Neolithic rock shelter of Mala Triglavca, Slovenia
}

\author{
Lucija Šoberl' ${ }^{1}$, Andreja Žibrat Gašparič ${ }^{2}$, Mihael Budja ${ }^{2}$ and Richard P. Evershed ${ }^{1 *}$ \\ 1 Organic Geochemistry Unit, School of Chemistry, University of Bristol, Bristol, UK \\ 2 Department of Archaeology, Faculty of Arts, University of Ljubljana, Ljubljana, SI \\ *author for correspondence: r.p.evershed@bristol.ac.uk
}

\begin{abstract}
A collection of pottery from the early Neolithic site of Mala Triglavca was analysed with the aim of obtaining insights into vessel use and early animal domestication and husbandry practices in the Adriatic region. Total lipid extracts were submitted to gas chromatography (GC), GC-mass spectrometry (GC-MS) and GC-combustion-isotope ratio MS (GC-C-IRMS) in order to obtain molecular and stable carbon isotope signatures as the basis for determining the nature and origins of the residues. The extracts were dominated by degraded animal fats. The majority (70\%) of the total lipid extracts displayed intact triacylglycerol distributions attributable to ruminant adipose and dairy fats, which were subsequently confirmed through $C_{16: 0}$ and $C_{18: 0}$ fatty acid $\delta^{13} \mathrm{C}$ values.
\end{abstract}

IZVLEČEK - Izbor keramičnih vzorcev iz zgodnje neolitskega najdišča Mala Triglavca je bil analiziran z namenom, da bi pridobili dodatne informacije o uporabi keramičnih posod ter značaju zgodnje živinoreje na Jadranskem prostoru. Lipidne ekstrakte vzorcev smo analizirali s pomočjo plinske kromatografije (GC), plinske kromatografije sklopljene z masno spektrometrijo (GC/MS) in plinske kromatografije sklopljene s sežigno masno spektrometrijo razmerij izotopov (GC-C-IRMS). V lipidnih ekstraktih so prevladovale živalske maščobe. V večini (70\%) lipidnih ekstraktov so bile prisotne nespremenjene trigliceridne distribucije, ki jih lahko pripišemo tolščnim ter mlečnim maščobam prežvekovalcev. Lipidni izvor je bil nadalje potrjen z $\delta_{13} \mathrm{C}$ vrednostmi prostih maščobnih kislin $C_{16: 0}$ in $C_{18: 0}$.

KEY WORDS - Neolithic, Adriatic, organic residues, fatty acyl lipids, ${ }^{13} \mathrm{C}$ values

\section{Introduction}

Organic residues survive in two principal forms in association with archaeological pottery, namely as: (i) surface residues appearing as visible residues on the exterior or interior of vessels, and (ii) as absorbed residues preserved within the vessel wall; invisible to the naked eye. The first class of residues, occurs on the exterior surfaces of and correspond to either sooting derived from heating on a fire or seemingly rather rare instances of applied decorations (Urem-Kotsou et al. 2002; Connan et al. 2004). Together with exterior sooting, the interior surface residues are probably the group of residues most familiar to pottery analysts. These are often carbonised, and presumed to be residues of 'cooking' failures, while post-firing treatments are also seen, particularly as copious linings associated with Roman amphorae (Beck et al. 1989). Absorbed residues are by far the most common in pottery and probably the most widely occurring residue type. Analyses performed to date suggest that absorbed organic residues survive in $>80 \%$ of domestic cooking pottery assemblages worldwide.

Lipids residues of cooking and the processing of other organic commodities have been found to survive in archaeological pottery vessels as components of surface and absorbed residues for several millennia. The most successful analytical approaches in- 
volve solvent extraction, then using a combination of instrumental analytical techniques, including: high temperature-gas chromatography (HTGC), GC/mass spectrometry (GC/MS; Evershed et al. 1990) and GCcombustion-isotope ratio MS (GC-C-IRMS; Evershed et al. 1994), to identify and quantify the components of the lipid extracts of such residues. Characterisation of lipid extracts to commodity type is only possible through detailed knowledge of diagnostic compounds and their associated degradation products formed during vessel use and/or burial. An increasing range of commodities is being detected in pottery vessels, including animals products (e.g. Evershed et al. 1992; Copley et al. 2003), leafy vegetables (Evershed et al. 1991; Evershed et al. 1994), specific plant oils (Condamin et al. 1976; Copley et al. 2005a) and beeswax (Heron et al. 1994; Evershed et al. 1997; Regert et al. 2001).

Animal fats are by far the most common residue identified from archaeological pottery, characterised by high abundances of free fatty acids, particularly palmitic $\left(\mathrm{C}_{16: 0}\right)$ and stearic acid $\left(\mathrm{C}_{18: 0}\right)$. Triacylglycerols (TAGs) are the major constituents of modern animal fats, however, they are degraded to diacylglycerols (DAGs), monoacylglycerols (MAGs) and free fatty acids during vessel use and burial, such that in archaeological pottery the free fatty acids tend to predominate. This has been observed in numerous pottery vessels (Evershed et al. 2001) and verified through laboratory degradation experiments (e.g. Charters et al. 1997; Dudd and Evershed 1998; Evershed 2008). Precise assigning of the origins of animal fats is only possible through the use of compound-specific stable carbon isotope analysis. GC-CIRMS allows the carbon stable isotope $\left(\delta^{13} \mathrm{C}\right)$ values of individual compounds (within a mixture) to be determined. It has been previously observed that the $\delta 13 \mathrm{C}$ values for the principal fatty acids $\left(\mathrm{C}_{16: 0}\right.$ and $\mathrm{C}_{18: 0}$ ) are crucial in distinguishing between different animal fats, e.g. ruminant and non-ruminant adipose fats and dairy fats (Evershed et al. 1997a, Dudd and Evershed 1998), as well as in the identification of the mixing of commodities (Evershed et al. 1999; Copley et al. 2001). Recently it has been demonstrated that dairy products were important commodities in Early Neolithic at various archaeological sites throughout Europe and Near East, as illustrated through the persistence of dairy fats in archaeological pottery vessels (Copley et al. 2003; 2005b; Evershed et al. 2008).

The aim of this investigation was to apply organic residue analysis to prehistoric pottery from the Neo- lithic rock shelter Mala Triglavca in order to determine the nature and origin of preserved lipids and thereby provide new insights into food preparation and consumption of the inhabitants. As a consequence of the wider interest in the use of rock shelters in the early Neolithic, the organic analysis of the pottery from this site offers an important opportunity to explore aspects of animal husbandry, particularly dairying.

\section{Sites and samples}

The Neolithic rock shelter site of Mala Triglavca is situated in the Dinaric karst in south-western Slovenia. There is evidence that the site has been continuously occupied from the Mesolithic until the Middle ages. Rock shelter sites in the region have mostly been interpreted in two different ways: (i) as seasonal camps for hunters/shepherds, or (ii) as places for long-term settlement. Archaeozoological remains discovered on the site mainly belong to domesticated animals (cattle, sheep, goat, dog) as well as wild animals (wild boar, red deer, roe deer). A total of 36 potsherds were selected for analysis from earliest Neolithic phase.

\section{Materials and methods}

Lipid analyses were performed using established protocols which are described in detail in earlier publications (Evershed et al. 1990; Charters et al. 1993b). Briefly, analyses proceeded as follows:

\section{Solvent extraction of lipid residues}

Lipid analyses of potsherds involved taking $c .2 \mathrm{~g}$ samples from area of the the sherd that had been surface-cleaned using a modelling drill to remove any exogenous lipids (e.g. soil or finger lipids due to handling). The sub-samples were then ground to a fine powder, accurately weighed and a known amount $(20 \mu \mathrm{g})$ of internal standard ( $n$-tetratriacontane) added, to enable determination of the lipid concentration. The lipids were extracted with a mixture of chloroform and methanol $(2: 1 \mathrm{v} / \mathrm{v})$. Following separation from the ground potsherd the solvent was evaporated under a gentle stream of nitrogen to obtain the total lipid extract (TLE). Portions (generally one third aliquots) of the extracts were then trimethylsilylated and submitted directly to analysis by HTGC. Where necessary combined GC/MS analyses were also performed on trimethylsilylated aliquots of the lipid extracts to enable the elucidation of structures of components not identifiable on the basis of HTGC retention time alone. 


\section{Preparation of trimethylsilyl derivatives}

Portions of the total lipid extracts were derivatised using $N, O$-bis(trimethylsilyl)trifluoroacetamide ( $40 \mu \mathrm{l}$; $70^{\circ} \mathrm{C} ; 60 \mathrm{~min}$; Sigma-Aldrich Company Ltd., Gillingham, UK) and analysed by HTGC and GC-MS.

\section{Saponification of total lipid extracts}

Methanolic sodium hydroxide (5\% v/v) was added to the TLE and heated at $70^{\circ} \mathrm{C}$ for $1 \mathrm{~h}$. Following neutralisation, lipids were extracted into chloroform and the solvent reduced under gentle stream of nitrogen.

\section{Preparation of methyl ester derivatives (FAMEs)}

FAMEs were prepared by reaction with $\mathrm{BF}_{3}$-methanol $(14 \% \mathrm{w} / \mathrm{v} ; 100 \mu \mathrm{l}$; Sigma-Aldrich, Gillingham, UK) at $70^{\circ} \mathrm{C}$ for $1 \mathrm{~h}$. The methyl ester derivatives were extracted with chloroform and the solvent removed under nitrogen. FAMEs were re-dissolved in hexane for analysis by GC and GC-C-IRMS.

\section{Results}

The HTGC and GC/MS analyses serve to quantify and identify compounds in the TLE, revealing the possible presence of: (i) animal fat or plant oil, and/ or (ii) plant epicuticular waxes, and/or (iii) beeswax or other sealants, and/or (iv) mid-chain ketones that indicate that the vessel has been heated (Evershed et al. 1995; Raven et al. 1997). Further analyses by GC-C-IRMS analyses can distinguish between ruminant and non-ruminant adipose fats and dairy fats by investigating the $\delta^{13} \mathrm{C}_{16: 0}$ and $\delta^{13} \mathrm{C}_{18: 0}$ values. Table 1 lists the sample designations, the concentrations of lipids detected and the assignments of the broad commodity groups present in individual sherds based on the molecular and isotopic compositions of the components of the TLEs. Ten of the sherds (28\%) yielded significant concentrations of lipid (i.e. $>5 \mu \mathrm{gg}^{-1}$ ) sufficient for further analysis by GC-MS and GC-C-IRMS.

Figure 1 shows a typical partial gas chromatogram for the TLE of sample 08MT, revealing the presence of free fatty acids, with high abundances of $\mathrm{C}_{16: 0}$ and $\mathrm{C}_{18: 0}$ components, mono-, di- and triacylglycerols (MAGs, DAGs, TAGs). The chromatogram also shows presence of odd carbon number saturated fatty acids, iso- and anteiso-branched odd carbon number fatty acids $\left(\mathrm{C}_{15: 0 b r}, \mathrm{C}_{17: 0 \mathrm{br}}\right)$, which may indicate a ruminant source (Mottram et al. 1999; Evershed et al. 2001). Traces of wax esters were also present eluting in the region of the TAGs.
MAGs, DAGs and TAGs, which are indicative of degraded animal fat were detected in 7 of the TLEs together with relatively high abundances of the palmitic $\left(\mathrm{C}_{16: 0}\right)$ and stearic $\left(\mathrm{C}_{18: 0}\right)$ free fatty acids, which as discussed above, are the terminal products of TAG hydrolysis. Previous work has shown that the TAG distributions can be linked to different sources, thereby allowing preliminary differentiation of fats of the two major classes of domestic animals (ruminant and non-ruminant) and ruminant dairy fats.

However, laboratory experiments have shown that TAG distributions can be skewed by degradation; the wide TAG distribution characteristic of fresh ruminant dairy fat is considerably narrowed, and thus comes to resemble the narrower distribution seen in ruminant adipose fat (Dudd et al. 1998; Dudd and Evershed 1998). Therefore conclusions drawn from TAG distributions have to be made with caution. The TAG distributions preserved in the extracts from the Mala Triglavca sherds are shown in Figure 3.

The total lipid extracts (TLEs) of samples 08MT, 18MT, 78MT, 79MT and 159MT displayed relatively broad TAG distributions with acyl carbon number range of $\mathrm{C}_{44}$ to $\mathrm{C}_{54}$, maximising at $\mathrm{C}_{50} / \mathrm{C}_{52}$. Such distributions are characteristic of reference ruminant adipose fat, or degraded milk fat. In contrast, the extract of 13MT displayed quite a narrow TAG distribu-

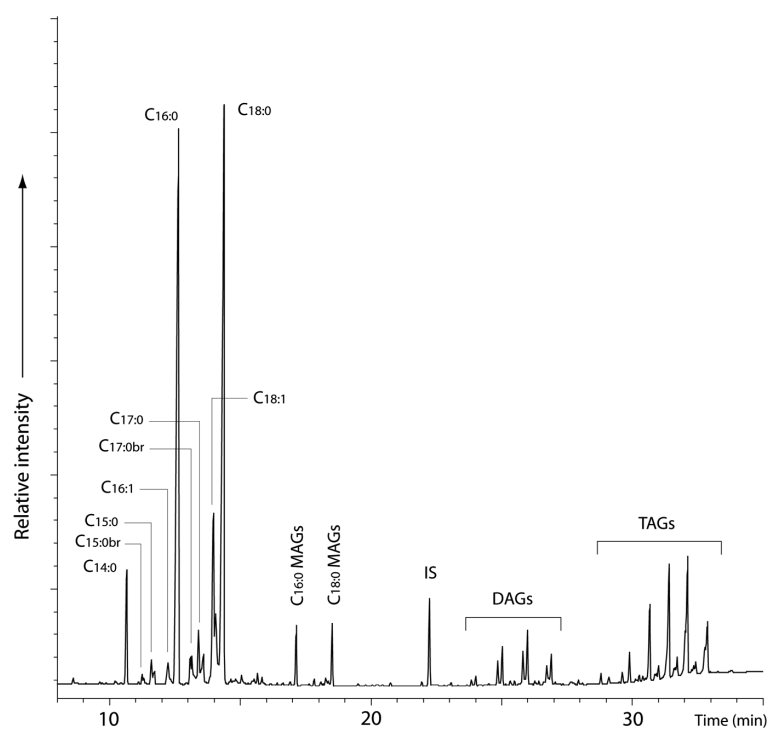

Fig. 1. Partial HTGC profile of the trimethylsilylated total lipid extract from sample 08MT, showing the distribution of components characteristic of degraded animal fat. Key: $C_{X: 0}$ are saturated free fatty acids of carbon length $x$, br stand for branched fatty acids, $I S$ is the internal standard ( $C_{34}$ n-alkane). MAGs are monoacylglycerols; $D A G s$ are diacylglycerols; TAGs are triacylglycerols. 


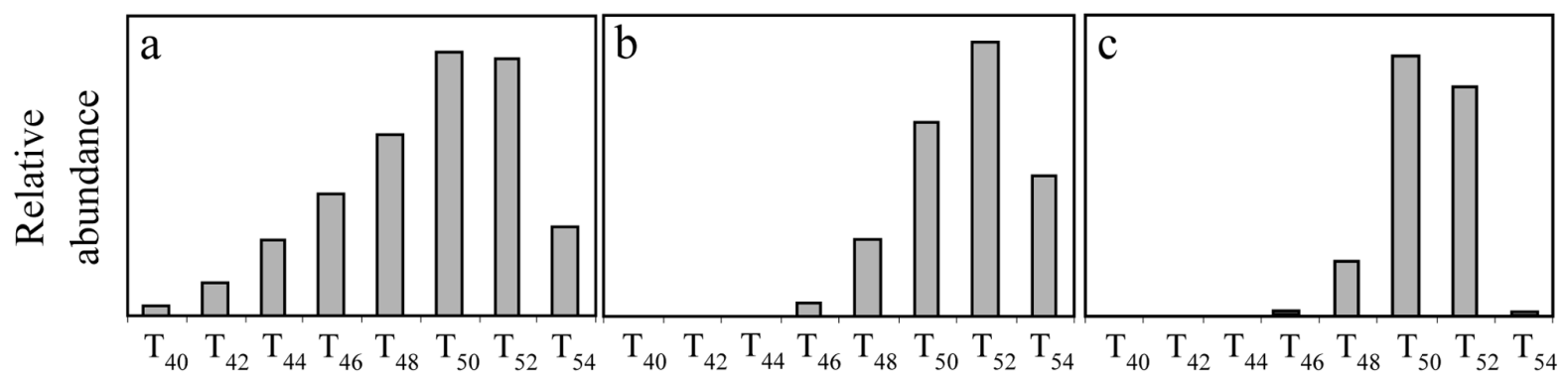

Acyl carbon number

Fig. 2. Histograms showing the typical acyl carbon number distributions expected for triacylglycerols deriving from degraded lipid residues obtained from: (a) ruminant dairy fat, (b) ruminant adipose, and (c) pig adipose (Berstan 2002).

tion, with an acyl carbon number range of $\mathrm{C}_{50}$ to $\mathrm{C}_{54}$, maximising at $\mathrm{C}_{52}$, which is identical to reference ruminant adipose fats (Fig. 2).

The 8 TLEs that yielded appreciable lipid concentrations analysed further by GC-C-IRMS to determine the $\delta 13 \mathrm{C}$ values for the major fatty acids $\left(\mathrm{C}_{16: 0}\right.$ and $\left.\mathrm{C}_{18: 0}\right)$; these values are plotted in Figure 4 . The $\delta^{13} \mathrm{C}$ values obtained for modern reference animal fats from the major domesticated animals exploited in prehistory are grouped within confidence ellipses, onto which the values from archaeological pottery are plotted. The $\delta^{13} \mathrm{C}$ values for the $\mathrm{C}_{18: 0}$ fatty acid are more depleted in milk fats than in ruminant adipose fats, thus enabling distinctions to be drawn between milk and adipose fats from ruminant animals (Dudd and Evershed 1998). This is witnessed in the c. $2.5 \%$ shift between centroids of the reference ruminant adipose fat and ruminant dairy fat ellipses. The less depleted $\delta^{13} \mathrm{C}$ values seen for the fatty acids in non-ruminant fats compared to equivalent compo- nents in ruminant fat are to be due to differences in diet and in the metabolic and biochemical processes involved in the formation of body fats in ruminant and non-ruminant animals.

The $\delta^{13 \mathrm{C}}$ values for the $\mathrm{C}_{16: 0}$ and $\mathrm{C}_{18: 0}$ fatty acids from 18MT, 79MT, $87 \mathrm{MT}, 88 \mathrm{MT}$ and 161MT plot within or adjacent to the dairy fat reference confidence ellipse, while that from 75MT plots within the ruminant adipose reference fat ellipse. Values from 08MT and 13MT plot between the porcine adipose fat and ruminant adipose fat ellipses. These $\delta^{13} \mathrm{C}$ values are most likely indicative of mixing of commodities in the vessels, which may have occurred through multiple use of the vessel or through the contemporaneous mixing of animal products.

The modern fats used to construct the reference isotope plot were reared on a strict $\mathrm{C}_{3}$ diet of fodders and cereals. The slight displacement of some of the $\delta^{13} \mathrm{C}$ values to the right of the mixing curves may be
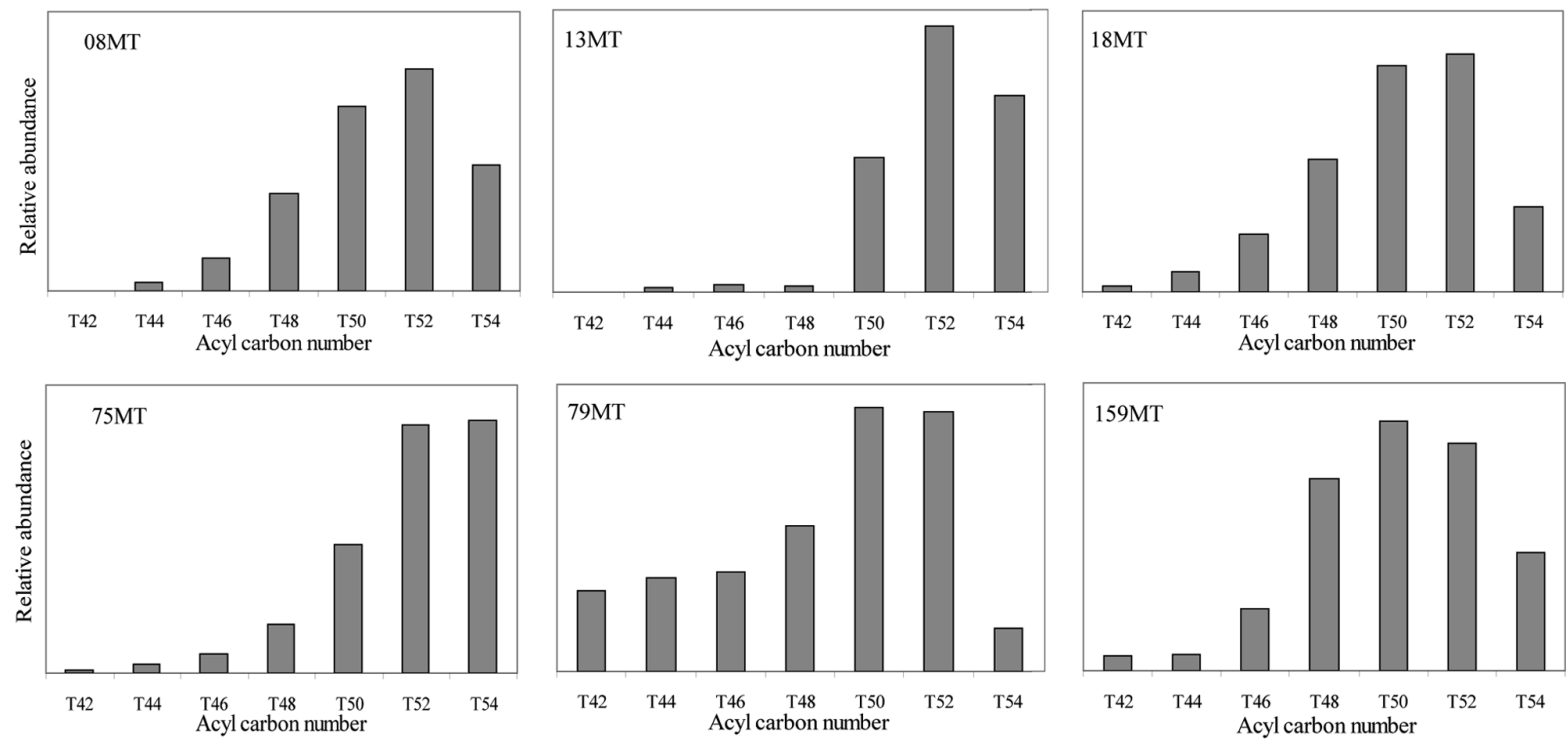

Fig. 3. The distributions of TAGs detected in the Mala Triglavca total lipid extracts. 


\begin{tabular}{|c|c|c|c|c|c|}
\hline \begin{tabular}{l|} 
Lab. \\
sample \\
no.
\end{tabular} & $\begin{array}{c}\text { Lipid } \\
\text { concentration } \\
\left(\mu g^{-1}\right)\end{array}$ & Lipids detected & $\begin{array}{l}\delta 13 C_{16: 0} \\
\pm 0.3(\% \circ)\end{array}$ & $\begin{array}{l}\delta 13 C_{18: 0} \\
\pm 0.3(\% \circ)\end{array}$ & $\begin{array}{l}\text { Predominant } \\
\text { commodity type }\end{array}$ \\
\hline o8MT & 173.35 & $\begin{array}{l}\text { FA (16<18; 14, 15, 15br,17, 17br, } \\
19,20) \text {, MAG, DAG, TAG, WE }\end{array}$ & -26.5 & -29.9 & mixture of animal fats \\
\hline ogMT & 1.90 & $\mathrm{n} / \mathrm{a}$ & $\mathrm{n} / \mathrm{a}$ & $\mathrm{n} / \mathrm{a}$ & $n / a$ \\
\hline $11 \mathrm{MT}$ & 0.81 & $\mathrm{n} / \mathrm{a}$ & $\mathrm{n} / \mathrm{a}$ & $\mathrm{n} / \mathrm{a}$ & $n / a$ \\
\hline $12 \mathrm{MT}$ & 0.42 & $\mathrm{n} / \mathrm{a}$ & $\mathrm{n} / \mathrm{a}$ & $\mathrm{n} / \mathrm{a}$ & $n / a$ \\
\hline $13 \mathrm{MT}$ & 11.56 & $\begin{array}{l}\text { FA }(16<18), \text { MAG, A, } \\
\text { OH, DAG, WE, TAG }\end{array}$ & -26.7 & -28.8 & ruminant adipose fat \\
\hline $14 \mathrm{MT}$ & 0.24 & $\mathrm{n} / \mathrm{a}$ & $\mathrm{n} / \mathrm{a}$ & $\mathrm{n} / \mathrm{a}$ & $n / a$ \\
\hline $15 \mathrm{MT}$ & 0.00 & $\mathrm{n} / \mathrm{a}$ & $\mathrm{n} / \mathrm{a}$ & $\mathrm{n} / \mathrm{a}$ & $n / a$ \\
\hline $16 \mathrm{MT}$ & 0.00 & $n / a$ & $\mathrm{n} / \mathrm{a}$ & $\mathrm{n} / \mathrm{a}$ & $n / a$ \\
\hline $17 \mathrm{MT}$ & 1.01 & $\mathrm{n} / \mathrm{a}$ & $\mathrm{n} / \mathrm{a}$ & $\mathrm{n} / \mathrm{a}$ & $n / a$ \\
\hline $18 \mathrm{MT}$ & 88.09 & $\begin{array}{c}\text { FA }(16<18 ; 14,15,15 \mathrm{br}, 17,17 \mathrm{br}, 18: 1, \\
19,20,21,22,23,24), \text { MAG, DAG, TAG }\end{array}$ & -27.7 & -33.3 & dairy fat \\
\hline $75 \mathrm{MT}$ & 90.54 & $\begin{array}{l}\text { FA }(16<18 ; 14,15,15 b r, 17,17 b r \\
18: 1,19,20) \text {, MAG, DAG, TAG }\end{array}$ & -29.0 & -31.5 & ruminant adipose fat \\
\hline $76 \mathrm{MT}$ & 2.92 & $n / a$ & $n / a$ & $\mathrm{n} / \mathrm{a}$ & $n / a$ \\
\hline $77 \mathrm{MT}$ & 0.00 & $n / a$ & $n / a$ & $\mathrm{n} / \mathrm{a}$ & $\mathrm{n} / \mathrm{a}$ \\
\hline $78 \mathrm{MT}$ & 2.58 & $n / a$ & $n / a$ & $\mathrm{n} / \mathrm{a}$ & $n / a$ \\
\hline $79 \mathrm{MT}$ & 27.23 & $\begin{array}{l}\text { FA (16>18; 14,17, 17br, 18:1, 19, } \\
20) \text {, MAG, OH, A, DAG, TAG, P }\end{array}$ & -27.8 & -32.9 & dairy fat \\
\hline $80 \mathrm{MT}$ & 3.45 & $n / a$ & $n / a$ & $n / a$ & $n / a$ \\
\hline $81 \mathrm{MT}$ & 1.34 & $n / a$ & $n / a$ & $\mathrm{n} / \mathrm{a}$ & $n / a$ \\
\hline $82 \mathrm{MT}$ & 0.00 & $n / a$ & $n / a$ & $\mathrm{n} / \mathrm{a}$ & $n / a$ \\
\hline $83 \mathrm{MT}$ & 3.12 & $\mathrm{n} / \mathrm{a}$ & $n / a$ & $\mathrm{n} / \mathrm{a}$ & $n / a$ \\
\hline $84 \mathrm{MT}$ & 1.10 & $\mathrm{n} / \mathrm{a}$ & $n / a$ & $\mathrm{n} / \mathrm{a}$ & $n / a$ \\
\hline $85 \mathrm{MT}$ & 1.34 & $\mathrm{n} / \mathrm{a}$ & $n / a$ & $\mathrm{n} / \mathrm{a}$ & $n / a$ \\
\hline $86 \mathrm{MT}$ & 1.38 & $n / a$ & $n / a$ & $\mathrm{n} / \mathrm{a}$ & $n / a$ \\
\hline $87 \mathrm{MT}$ & 21.93 & $\begin{array}{l}\text { FA }(16>18 ; 14,17,17 b r \\
18: 1,19,20), O H, A, P\end{array}$ & -27.3 & -32.2 & dairy fat \\
\hline $88 \mathrm{MT}$ & 9.93 & FA $(16>18 ; 14,20), P$ & -27.0 & -31.9 & dairy fat \\
\hline $89 \mathrm{MT}$ & 0.00 & $\mathrm{n} / \mathrm{a}$ & $n / a$ & $n / a$ & $n / a$ \\
\hline $156 \mathrm{MT}$ & 10.06 & FA $(16>18 ; 18: 1), P$ & $\mathrm{n} / \mathrm{a}$ & $\mathrm{n} / \mathrm{a}$ & $?$ \\
\hline $157 \mathrm{MT}$ & 4.06 & $\mathrm{n} / \mathrm{a}$ & $n / a$ & $\mathrm{n} / \mathrm{a}$ & $n / a$ \\
\hline $158 \mathrm{MT}$ & 0.98 & $\mathrm{n} / \mathrm{a}$ & $n / a$ & $\mathrm{n} / \mathrm{a}$ & $\mathrm{n} / \mathrm{a}$ \\
\hline $159 \mathrm{MT}$ & 12.65 & FA $(16>18)$, MAG, DAG, TAG, P & $\mathrm{n} / \mathrm{a}$ & $\mathrm{n} / \mathrm{a}$ & dairy fat? \\
\hline $160 \mathrm{MT}$ & 5.53 & $\mathrm{n} / \mathrm{a}$ & $\mathrm{n} / \mathrm{a}$ & $\mathrm{n} / \mathrm{a}$ & $n / a$ \\
\hline $161 \mathrm{MT}$ & 43.81 & FA $(16<18)$, MAG, DAG & -29.5 & -34.1 & dairy fat \\
\hline $162 \mathrm{MT}$ & 2.77 & $\mathrm{n} / \mathrm{a}$ & $n / a$ & $\mathrm{n} / \mathrm{a}$ & $\mathrm{n} / \mathrm{a}$ \\
\hline $163 \mathrm{MT}$ & 4.02 & $\mathrm{n} / \mathrm{a}$ & $\mathrm{n} / \mathrm{a}$ & $\mathrm{n} / \mathrm{a}$ & $\mathrm{n} / \mathrm{a}$ \\
\hline $164 \mathrm{MT}$ & 2.47 & $\mathrm{n} / \mathrm{a}$ & $\mathrm{n} / \mathrm{a}$ & $\mathrm{n} / \mathrm{a}$ & $n / a$ \\
\hline $165 \mathrm{MT}$ & 1.53 & $\mathrm{n} / \mathrm{a}$ & $\mathrm{n} / \mathrm{a}$ & $\mathrm{n} / \mathrm{a}$ & $\mathrm{n} / \mathrm{a}$ \\
\hline $166 \mathrm{MT}$ & 4.67 & $\mathrm{n} / \mathrm{a}$ & $\mathrm{n} / \mathrm{a}$ & $\mathrm{n} / \mathrm{a}$ & $n / a$ \\
\hline
\end{tabular}

Tab. 1. Summary of the results of the organic residue analyses of Mala Triglavca early Neolithic potsherds.

Key: FA refers to free fatty acids, MAG to monoacylglycerols; DAG to diacylglycerols; TAG to triacylglycerols; $A$ are n-alkanes, $K$ are mid chain ketones, WE are wax esters, $P$ are plasticizers and nd $=$ none detected. Annotation 18:1 refers to the level of unsaturation and 17br to branched free fatty acids. 


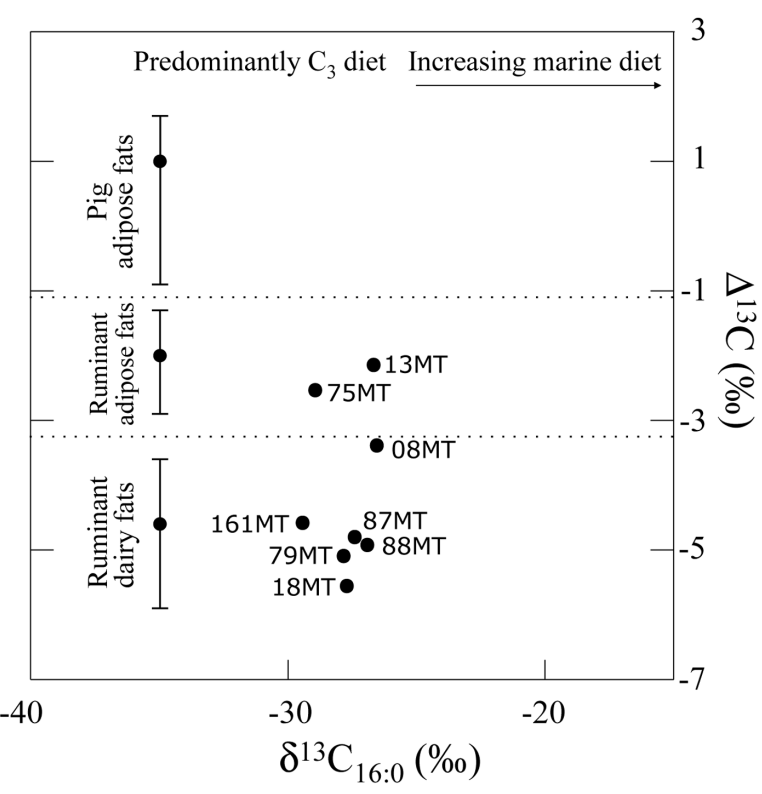

Fig. 5. A plot showing the difference between $\Delta^{13} \mathrm{C}$ values $\left(\delta^{13} C_{18: 0}-\delta^{13} C_{16: 0}\right)$ and $\delta^{13} C$ values obtained from the $C_{16: 0}$ fatty acids extracted from the Mala Triglavca potsherds. The ranges for the modern reference fats are plotted to the left of the diagram.

due to the fact that the animals in prehistory were reared on diets, which varied in $\delta^{13} \mathrm{C}$ values compared to today's values today environmental influences. $\Delta^{13} \mathrm{C}$ values $\left(\delta^{13} \mathrm{C}_{16: 0}-\delta^{13} \mathrm{C}_{18: 0}\right)$ are also a useful indicator of lipid origin where such variations exist. Figure 5 displays the $\Delta^{13} \mathrm{C}$ values plotted against $\delta 13 \mathrm{C}_{16: 0}$ values for the Mala Triglavca potsherd fatty acids. The ranges on the left side of the graph are from the modern reference fats.

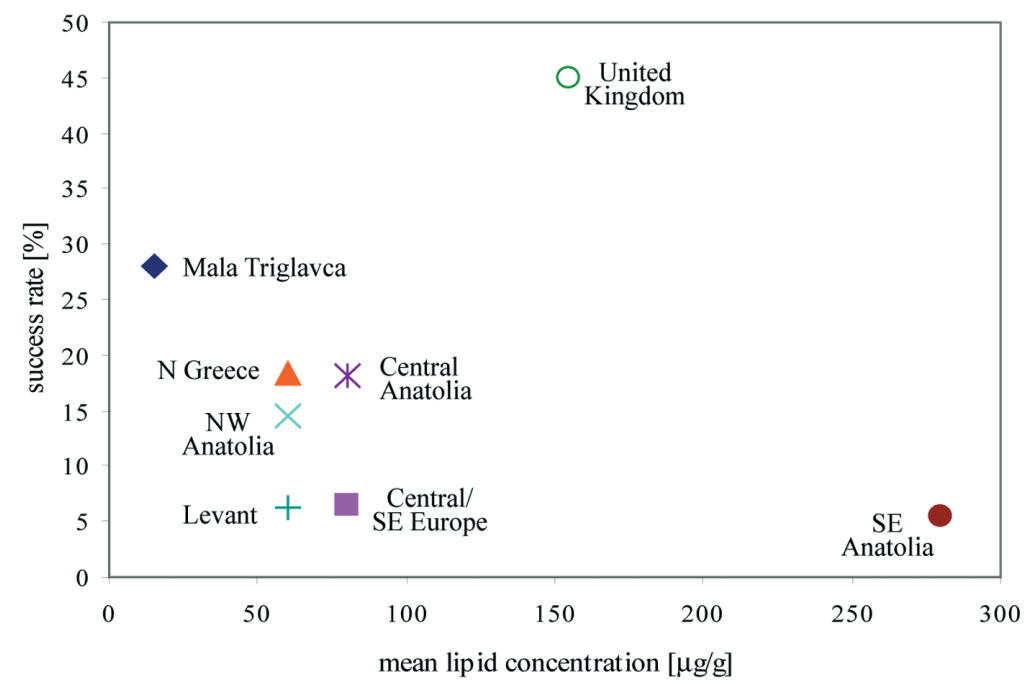

Fig. 6. A plot showing the correlation between success rate (which is number of TLEs with appreciable lipid concentration divided by total number of samples analysed) and mean lipid concentration for Mala Triglavca and other regions with evidences for early Neolithic milk use.

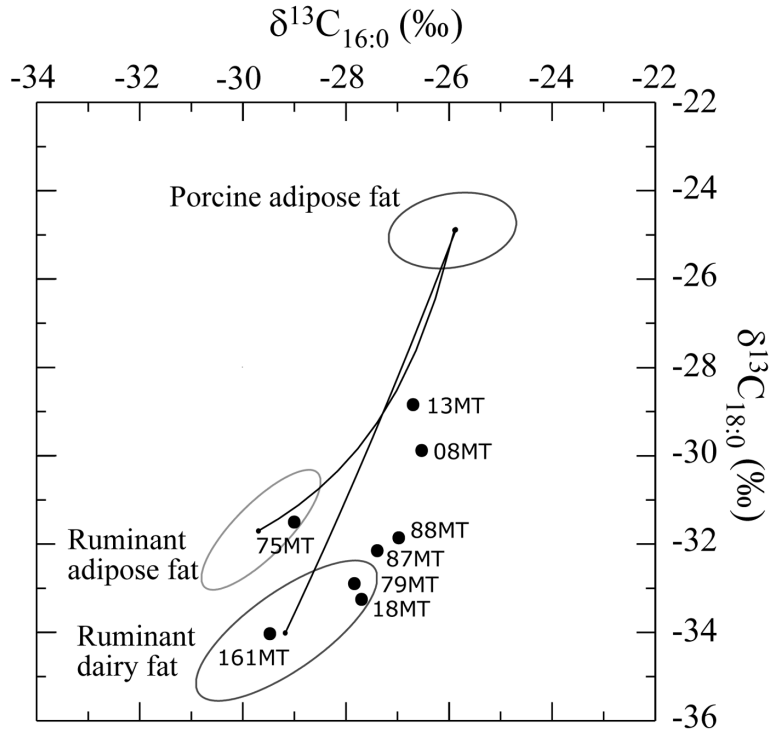

Fig. 4. Scatter plot showing the $\delta 13 \mathrm{C}$ values of $C_{16: 0}$ and $C_{18: 0}$ fatty acids prepared from total lipid extracts of Mala Triglavca potsherds. The values of modern reference fats are represented by confidence ellipses (1 standard deviation). Lines connecting the ellipses represent theoretical $813 \mathrm{C}$ values obtained through the mixing of these fats.

Using Figure 5, it was possible to more securely attribute the Mala Triglavca residues to their potential lipid sources. Sample 13MT, which was plotted on Figure 4 in between the ruminant dairy and adipose reference ellipse, can now be more accurately attributed to the latter, together with 75MT. Unfortunately, the same could not be achieved for TLE of sample 08MT, which remains plotted on the boarder of two ranges and most likely the consequence of mixing of different types of fat during the pottery use.

\section{Discussion}

The lipid components of the organic residues preserved in the early Neolithic vessels from Mala Triglavca displayed reasonable preservation given their age, with appreciable TLEs being detected in $28 \%$ of the sherds analysed. The high degree of preservation overall was also reflected in the survival of acylglycerol components (MAGs, DAGs and TAGs) in a significant proportion $(70 \%)$ of TLEs. Although somewhat later age the lipid residues from Mala Triglavca show similar rate of recovery and mean concentrations to those observed in early 
Neolithic pottery from SE Europe, Turkey and Near East (Fig. 6; Evershed et al. 2008). Interestingly, dairy fats dominate the preserved lipids at Mala Triglavca, and display a mean lipid concentration of $15 \mu \mathrm{gg}^{-1}$, which is comparable to the concentration seen in pottery from the other regions where early Neolithic milk use has been demonstrated. The concentrations and rate of recovery of lipid from British Neolithic pottery are both significantly higher than the more southerly located sites and likely reflect preservational differences related to climate and age (Copley et al. 2005b).

Returning to the Mala Triglavca residues there is also a good correlation between the triacylglycerol distributions preserved and interpretations of ruminant dairy and adipose fats in pottery based upon stable carbon isotope values. None of the total lipid extracts contained porcine adipose fat, which agrees with the low percentages of pigs in faunal assemblage from the site, which is dominated by small cattle and sheep/goat. The latter clearly correlates with the fat type detected in the pottery, although the fats from the different species cannot be separated. Interestingly, Mlekuž has recently managed to partially reconstruct herd structures using faunal remains from early Neolithic sites on the Adriatic coast. The earliest animal domestication and husbandry appears to have involved exploitation of both animal meat as well as dairy products (Mlekuž 2006). Analyses of absorbed lipid residues of pottery from Mala Triglavca confirm this interpretation - the Neolithic inhabitants of the site were using diverse domesticated animal products in every day food preparation and consumption. Since no mid-chain ketones were present in any of the extracts it appears that the vessels were not heated to high temperatures $\left(>300^{\circ} \mathrm{C}\right)$ during use (Raven et al. 1997).

In summary, the results obtained from lipid analyses of the Mala Triglavca pottery is consistent with on-going debate concerning the integration of animal domestication into early farming as part of the Neolithisation process along the Adriatic coast. The results concur with recent findings from organic residue analyses of Neolithic pottery from the SE Europe and Near East, where it has been shown that the early use of dairy products dates back at least to

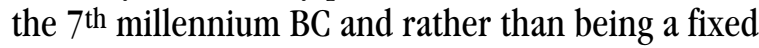
package, likely developed in different ways and in different geographical regions (Evershed et al. 2008; Mlekuž et al. 2008).

\section{ACKNOWLEDGEMENTS}

This research was undertaken while LS was in receipt of a EU Leonardo da Vinci Scholarship. Drs R. Berstan and I. D. Bull are thanked for technical support. The NERC are thanked for mass spectrometry facilities. The UK Joint Higher Education Funding Council for England and Office of Science and Technology Science Research Investment Fund (SRIF), and the University of Bristol are thanked for infrastructure funding.

\section{REFERENCES}

BECK C. W., SMART C. and OSSENKOP D. 1989. Residues and Linings in Ancient Mediterranean Transport Amphoras. Archaeological Chemistry 4: 69-380.

BERSTAN R. 2002. Compound-Specific $\delta^{13} \mathrm{C}$ and ${ }^{14} \mathrm{C}$ Determinations of Archaeological Animal fats (Doctoral thesis defended at University of Bristol).

CHARTERS S., EVERSHED R. P., GOAD L. J., LEYDEN A., BLINKHORN P. W. and DENHAM V. 1993. Quantification and distribution of lipid in archaeological ceramics: implications for sampling potsherds for organic residue analysis and the classification of vessel use. Archaeometry 35: 211-223.

CHARTERS S., EVERSHED R. P., BLINKHORN P. W. and DENHAM V. 1995. Evidence for the mixing of fats and waxes in archaeological ceramics. Archaeometry 37: 113127.

CHARTERS S., EVERSHED R. P., QUYE A., BLINKHORN P. W. and REEVES V. 1997. Simulation experiments for determining the use of ancient pottery vessels: The behaviour of epicuticular leaf wax during boiling of a leafy vegetable. Journal of Archaeological Science 24: 1-7.

CONDAMIN J., FORMENTI F., METAIS M. O., MICHEL M. and BLOND P. 1976. The application of gas chromatography to the tracing of oil in ancient amphorae. Archaeometry 18: 195-201.

CONNAN J., NIEUWENHUYSE O. P., VAN AS A. and JACOBS L. 2004. Bitumen in early ceramic art: bitumenpainted ceramics from Late Neolithic Tell Sabi Abyad (Syria). Archaeometry 46: 115-124. 
COPLEY M. S., BERSTAN R., DUDD S. N., DOCHERTY G., MUKHERJEE A. J., STRAKER V., PAYNE S. and EVERSHED R. P. 2003. Direct chemical evidence for widespread dairying in prehistoric Britain. Proceedings of the National Academy of Sciences 100: 1524-1529.

COPLEY M. S., BLAND H. A., ROSE P., HORTON M. and EVERSHED R. P. 2005a. Gas chromatographic, mass spectrometric and stable carbon isotopic investigations of organic residues of plant oils and animal fats employed as illuminants in archaeological lamps from Egypt. Analyst 130: $860-871$.

COPLEY M. S., BERSTAN R., DUDD S. N., AILLAUD S., MUKHERJEE A. J., STRAKER V., PAYNE S. and EVERSHED R. P. $2005 \mathrm{~b}$. Processing of milk products in pottery vessels through British prehistory. Antiquity 79: 895-908.

DUDD S. N. and EVERSHED R. P. 1998. Direct demonstration of milk as an element of archaeological economies. Science 282: 1478-1481.

EVERSHED R. P. 1993. Biomolecular archaeology and lipids. World Archaeology 25: 74-93.

2008. Experimental approaches to the interpretation of absorbed organic residues in archaeological ceramics. World Archaeology 40: 26-47.

EVERSHED R. P., HERON C. and GOAD L. J. 1990. Analysis of organic residues of archaeological origin by high-temperature gas-chromatography and gas-chromatography mass- spectrometry. Analyst 115: 1339-1342.

1991. Epicuticular wax components preserved in potsherds as chemical indicators of leafy vegetables in ancient diets. Antiquity 65: 540-544.

EVERSHED R. P., HERON C., CHARTERS S. and GOAD L. J. 1992. In A. M. Pollard (ed.), New Developments in Archaeological Science. Oxford University Press, Oxford: 187208.

EVERSHED R. P., ARNOT K. I., COLLISTER J., EGLINTON G. and CHARTERS S. 1994. Application of isotope ratio monitoring gas-chromatography mass-spectrometry to the analysis of organic residues of archaeological origin. Analyst 119: 909-914.

EVERSHED R. P., VAUGHAN S. J., DUDD S. N. and SOLES J. S. 1997. Fuel for thought? Beeswax in lamps and conical cups from the late Minoan Crete. Antiquity 71: 979985.

EVERSHED R. P., DUDD S. N., CHARTERS S., MOTTRAM H., STOTT A. W., RAVEN A., VAN BERGEN P. F. and BLAND H. A. 1999. Lipids as carriers of anthropogenic signals from prehistory. Philosophical Transactions of the Royal Society of London Series B-Biological Sciences 354: 19-31.

EVERSHED R. P., DUDD S. N., COPLEY M. S., BERSTAN R., STOTT A. W., MOTTRAM H. R., BUCKLEY S. A. and CROSSMAN Z. 2001. Chemistry of archaeological animal fats. Accounts of chemical research 35: 660-668.

EVERSHED R. P., PAYNE S., SHERRATT A. G., COPLEY M. S., COOLIDGE J., UREM-KOTSOU D., KOTSAKIS K., ÖZDOĞAN M., ÖZDOĞAN A. E., NIEUWENHUYSE 0., AKKERMANS P. M. M. G., BAILEY D., ANDEESCU R. R., CAMPBELL S., FARID S., HODDER I., YALMAN N., ÖZBAŞARAN M., BIÇAKCI E., GARFINKEL Y., LEVY T. and BURTON M. M. 2008. Earliest date for milk use in The Near East and southeastern Europe linked to cattle herding. Nature 455: 528-531.

HERON C., NEMCEK N. and BONFIELD K. M. 1994. The chemistry of Neolithic beeswax. Naturwissenschaften 81: 266-269.

MLEKUŽ D. 2006. Meat or milk? Neolithic economies of Caput Adriae. Preistoria dell'Italia settentrionale. Studi in ricordo di Bernardino Bagolini, Atti del Convegno, Udine settembre 2005, 453- 458 .

MLEKUŽ D., BUDJA M., PAYTON R. and BONSALL C. 2008. "Mind the Gap": Caves, Radiocarbon Sequences, and the Mesolithic-Neolithic Transition in Europe - Lessons from the Mala Triglavca Rockshelter Site. Geoarchaeology: An International Journal 23: 398-416.

MOTTRAM H. R., DUDD S. N., LAWRENCE G. J., STOTT A. W. and EVERSHED R. P. 1999. New chromatographic, mass spectrometric and stable isotope approaches to the classification of degraded animal fats preserved in archaeological pottery. Journal of Chromatography A. 833: 209-221.

RAVEN A. M., VAN BERGEN P. F., STOTT A. W., DUDD S. N. and EVERSHED R. P. 1997. Formation of long chain ketones in archaeological pottery by pyrolysis of acyl lipids. Journal of Analytical and Applied Pyrolysis 40/41: 267285.

REGERT M., COLINART S., DEGRAND L. and DECAVALLAS 0. 2001. Chemical alteration and use of beeswax through time: accelerated ageing tests and analysis of archaeological samples from various environmental contexts. Archaeometry 43: 549-569.

UREM-KOTSOU D., STERN B., HERON C. and KOTSAKIS K. 2002. Birch-bark tar at Neolithic Makriyalos, Greece. Antiquity 76: 962-967. 